\title{
PARADIGMA EKOLOGI DALAM KAJIAN SASTRA
}

\author{
Kaswadi \\ Universitas Wijaya Kusuma Surabaya
}

\begin{abstract}
ABSTRAK
Sebagaimana dikemukakan para pakar sastra bahwa karya sastra tidak berangkat dari kekosongan budaya, sistem sastra tertentu tidak tumbuh dan berkembang dalam isolasi mutlak, kemunculan karakteristik tertentu pada karya bukanlah sesuatu yang khas secara inheren pada dirinya sendiri. Hal-hal tersebut memiliki hubungan dengan aspek-aspek lain di luar sastra. Pendapat-pendapat tersebut menegaskan bahwa eksistensi karya sastra terkait dengan ekologinya. Yang dimaksud ekologi adalah segala sesuatu yang melingkupi proses dan karenanya menginspirasi penciptaan karya satra. Dalam paradigma ekologis, karya sastra diposisikan sebagai suatu species atau komponen dalam sebuah ekosistem. Hidup dan berkembangnya sebuah karya sastra adalah akibat aksi dan reaksi ekologis dalam kondisi ekosistem tertentu yang kompleks dan kait-mengkait. Dalam paradigma ekologi, kemunculan karya sastra bisa dipandang sebagai bukti adanya evolusi, adaptasi, atau kemungkinan-kemungkinan unik lainnya. Kajian ekologi terhadap karya sastra dimungkinkan karena ada kesejajaran antara fenomena karya sastra dan fenomena organisme dalam ekosistemnya. Oleh karena itu, kajian ekologi terhadap karya sastra juga dapat memanfaatkan pendekatan-pendekatan dalam penelitian ekologi.
\end{abstract}

Kata kunci: ekologi alam, ekologi budaya, kajian sastra, paradigma ekologi

\begin{abstract}
As has been convinced by literary scholars, literature does not depart from culture emptiness, a particular literary system does not grow in absolute isolation, the emergence of certain characteristic of literary work is not a specific inherent in itself. Those things have closely connection with other aspects outside literature. These statements admit that literary existence is related to its ecology. What meant by ecology is everything which surrounds a process and this what inspires the creation of literary work. In paradigm of ecology, literature is placed as a species or a component in a ecosystem. The life and the development of literary work are caused by ecological action and reaction in a certain interrelated complex ecosystem. In paradigm of ecology, the emergence of literature is viewed as an approve of the evolution, adaptation, or some other uniqe possibilities. Ecology study on works of literature is possibly carried out for its balance position between literature and organism phenomena in its ecosystem. Thus, ecology stydy on literary works can also be using some approaches in ecology research.
\end{abstract}


Keywords: natural ecology, cultural ecology, literary study, paradigm ecology.

\section{PENDAHULUAN}

Sebagai produk budaya, fenomena karya sastra memiliki keparalelan dengan fenomena kehidupan manusia. Tingkat kekompleksan karya sastra paralel dengan tingkat kekompleksan kehidupan manusia. Hal tersebutkan disebabkan oleh karya sastra pada dasarnya bersumber dari, berbicara tentang, dan untuk kehidupan manusia. Fenomena kehidupan sebagai ekologi yang mengitari memunyai peran penting dalam penjadian karya sastra sebagai sumber, media, atmosfir, dan sasaran karya sastra.

Stanton (2012:112-114) mengemukakan bahwa penciptaan karya sastra memiliki kaitan dengan pandangan dunia pengarang yang dibentuk oleh berbagai pengalaman hidupnya. Stanton membagi pengalaman tersebut ke dalam empat elemen pokok. Bagian pertama berasal dari kedalaman individu sedangkan bagian yang lain bermula dari dunia eksternalnya. Individu terdiri atas dua elemen, yaitu emosi dan akal atau yang lazim disebut hati dan otak. Emosi adalah tempat individu hidup. Dunia eksternal dapat dipilah menjadi (1) fenomena fisis atau fakta yang dilihat, didengar, dan disentuh oleh individu, dan (2) makna, tidak terlihat dari fenomena tersebut, kekuatan dan hukum yang melingkupi baik yang bersifat ilmiah, ekonomis, politis, moral, maupun spiritual.

Pembagian elemen pokok pengalaman Stanton tersebut, memiliki kemiripan dengan pembagian pengalaman manusia oleh Ernst Bloch sebagaimana dikutip oleh Schillebeeckx (Sastrapratedja, 1982:ix). Menurutnya, pengalaman manusia merupakan suatu rangkaian antropological constans, yaitu dorongan-dorongan dan orientasi tetap manusia. Ada sekurang-kuangnya enam antropological constans yang bisa ditarik dari pengalaman sejarah manusia. (1) Relasi manusia dengan kejasmanian, alam, dan lingkungan ekologis. (2) Keterlibatan dengan sesama. (3) Keterikatan dengan struktur sosial dan institusi. (4) Ketergantungan masyarakat dan kebudayaan pada waktu dan tempat. (5) Hubungan timbal balik antara teori dan praksis. (6) Kesadaran relegius atau parareligius.

Kenyataan tersebut memperlihatkan kompleksitas pengalaman manusia yang merupakan hasil interaksi manusia, baik sebagai individu maupun makhluk 
sosial, dengan berbagai ekologi yang mengitarinya yang kompleks pula. Apabila manusia tersebut seorang pengarang, pengalaman-pengalaman hidup tersebut kemudian turut membentuk karya-karya sastra yang ditulisnya.

Menyadari kekompleksan karya sastra, sudah sewajarnya dalam rangka memahaminya perlu dilakukan upaya kreatif dengan selalu menggali, menemukan berbagai teori sesuai dengan fenomena dan karakteristik karya sastra. Hal itu yang menyebabkan dari waktu ke waktu selalu muncul teori-teori sastra yang baru sebagai upaya memahami karya sastra. Dengan pemikiran seperti itu, dalam makalah ini diajukan cara kajian sastra dengan paradigma ekologi, kajian sastra yang mempertimbangkan atau mengaji aspek-aspek ekologi yang melingkupi penciptaan karya sastra.

\section{PEMBAHASAN}

\section{Ekologi dan Karya Sastra}

Kebudayaan sebagai sistem budaya merupakan seperangkat gagasan yang membentuk tingkah laku seseorang atau kelompok dalam suatu ekosistem. Dalam rangka proses penjadian kebudayaan tersebut diperlukan adaptasi yang mengacu pada proses interaksi antara perubahan yang ditimbulkan oleh suatu organisme pada suatu lingkungan dan perubahan yang ditimbulkan oleh lingkungan dari organisme tersebut. Dengan kebudayaannya, untuk jangka waktu panjang yang telah dijalaninya, makhluk manusia berkembang dan tetap survival karena mampu melakukan proses penyesuaian timbal balik (Poerwanto, 2005:61). Oleh karena itu, kebudayaaan sebagai ciptaan atau warisan hidup bermasyarakat adalah hasil daya cipta atau kreativitas para pendukungnya dalam rangka berinteraksi dengan ekologinya (Poerwanto, 2005:91).

Hoed mengemukakan bahwa produk budaya mencerminkan nilai-nilai, pemikiran, suasana hati, perasaan, kepercayaan, dan adat kebiasaan masyarakat tempatan. Hal itu menunjukkan eratnya hubungan antara "tanda" dan "petanda". Tanda atau hasil perilaku sebagai produk budaya dapat mengarah pada perilaku verbal dalam bentuk teks sebagaimana halnya karya sastra dan pemberi tanda dapat mengarah pada penghasil perilaku verbal berbentuk teks, yang dalam hal ini, pengarang. Pengarang yang juga anggota masyarakat, tidak lain adalah tanda 
atau sebuah produk budaya yang dihasilkan oleh petanda, dalam hal ini adalah kelompok masyarakat dan alam sekitar (Fabiola, 2009:225-226).

Mengacu pada pendapat tersebut, karya sastra, yang juga merupakan produk budaya, juga merupakan bentuk atau cara penyampaian dan pola perilaku masyarakat dalam mencapai tujuan tertentu yang memiliki keterkaitan dengan lingkungannya. Lingkungan menjadi faktor penting bahkan penentu dalam proses penjadian sebuah karya sastra.

Para pakar berpendapat sastra tidak berangkat dari kekosongan budaya. Teeuw (2013:253), mengemukakan bahwa sistem sastra tertentu tidak tumbuh dan berkembang dalam isolasi mutlak. Senada dengan pendapat Teeuw tersebut, Pujiharto (2010:65), mengemukakan bahwa kemunculan karakteristik tertentu pada karya fiksi bukanlah sesuatu yang khas secara inheren pada dirinya sendiri. Hal tersebut memiliki hubungan dengan aspek-aspek lain di luar dirinya: aspek ekonomi, aspek sosial, aspek budaya, dan lain sebagainya. Pendapat-pendapat tersebut juga menegaskan bahwa dalam rangka pemahaman karya sastra, telaah ekologi karya sastra penting dilakukan.

Ekologi adalah ilmu pengetahuan antara organisme dan lingkungannya (McNaughton dan Wolf, 1998:1). Odum (1996:3) mendefinisikan ekologi sebagai disiplin ilmu yang mengaji hubungan organisme-organisme atau kelompok organisme, seperti manusia, hewan, tumbuhan, dengan lingkungannya. Istilah ekologi pertama kali digunakan oleh Reiter pada tahun 1865, kemudian dikemukakan oleh Haeckle, pakar biologi berkebangsaan Jerman pada tahun 1869. Haeckle mendefinisikan ekologi sebagai suatu keseluruhan pengetahuan yang berkaitan dengan hubungan-hubungan total antara organisme dengan lingkungannya yang bersifat organik dan anorganik (McNaughton dan Wolf, 1998:1).

Dewasa ini ekologi telah mengalami perkembangan pesat. Para ahli ekologi telah memelajari habitat dengan pengamatan yang amat berbeda, misalnya, lingkungan perkotaan, batu karang, bahkan tabung-tabung kultur di dalam laboratorium yang berisi bermacam-macam media pertumbuhan (Mcnaught dan Wolf, 1998:2). Perkembangan ekologi juga tampak pada munculnya berbagai 
studi interdisiplin. Ekologi tidak lagi terbatas pada kajian ekosistem atau alam, tetapi juga dipakai untuk mengaji bidang-bidang lainnya.

Studi interdisipliner yang dimaksud, misalnya ekologi bahasa. Istilah ekologi bahasa (language ecology) diperkenalkan oleh Haugen dalam bukunya yang berjudul The Ecology of Language (Suparwa, 1988:1). Ekologi bahasa di didefinisikan sebagai studi tentang interaksi antara bahasa dengan lingkungannya (Haugen, 1972; Kridalaksana, 1982:39). Lingkungan bahasa dalam pengertian ini menyangkut pemakaian bahasa sebagai sebuah kode (tanda) yang digunakan sebagai alat komunikasi oleh suatu masyarakat. Dengan demikian, bahasa diartikan sebagai kosa kata referensial dari suatu masyarakat dan gramatika atau tata bahasanya dan lingkungan diartikan sebagai masyarakat pemakai bahasa tersebut yang meliputi lingkungan alam dan lingkungan sosial (Suparwa, 1988:12).

Kajian ekologi bahasa juga dilakukan oleh Suparwa (2008) terhadap bahasa Melayu Loloan Bali. Bahasa Melayu loloan Bali Bahasa Melayu Loloan Bali adalah bahasa yang digunakan oleh komunitas yang menamakan dirinya "orang Loloan" sebagai penutur inti. Daerah pemakaian bahasa tersebut meliputi Loloan Barat dan Loloan Timur sebagai daerah pusat serta beberapa daerah pesisir pantai Kecamatan negara dan Melaya, seperti Banyubiru, Cupel, dan melaya Bawah sebagai daerah perkembangan. Dalam kajian ini, Suparwa menunjukkan bahwa perkembangan Bahasa Melayu Loloan Bali dipengaruhi oleh ekologinya yang meliputi: (1) lingkungan bahasa, (2) lingkungan alam. (3) lingkungan sosial, dan (4) lingkungan religi. Pengaruh ekologi tersebut dapat dilihat pada kosa kata, bunyi, dan bidang-bidang bahasa lainnya.

Kajian ekologi terhadap karya sastra mempertemukan ekologi dengan karya sastra. Paradigma ekologi terhadap kajian sastra berarti menerapkan pendekatan ekologi untuk mendekati karya sastra. Dalam pandangan ekologi, eksistensi organisme dipengaruhi oleh lingkungannya atau ada hubungan timbal balik dan saling keterkaitan antara organisme dengan lingkungannya. Lingkungan berarti semua faktor eksternal yang langsung memengaruhi kehidupan, pertumbuhan, perkembangan, dan reproduksi organisme. Dalam paradigma ekologis, karya sastra diposisikan sebagai suatu species atau komponen dalam sebuah ekosistem. 
Hidup dan berkembangnya sebuah karya sastra adalah akibat aksi dan reaksi ekologis dalam kondisi ekosistem tertentu yang kompleks dan kait-mengkait.

Aspek-aspek tertentu dalam ekologi dapat diteladani dan dimanfaatkan dalam penelitian sastra. Hal tersebut memungkinkan karena secara ekologis, ada kesejajaran antara fenomena karya sastra dengan fenomena organisme dalam lingkungannya. Keduanya sama-sama merupakan suatu komponen dari suatu ekosistem tertentu dan tumbuh dan berkembang dalam hubungan dengan komponen-komponen ekosistem yang lain.

McNaughton dan Wolf (1989:13) mengemukakan bahwa ada tiga pertanyaan ekologis penting dalam kajian ekologis. Pertama, organismeorganisme dan faktor-faktor lingkungan apa yang terdapat di suatu wilayah tertentu dan berapa jumlahnya? Kedua, bagaimana organisme-organisme tersebut beserta faktor-faktor lingkungannya terkait secara fungsional? Bagaimanakah hubungan tersebut, sama atau berbeda, di dalam ekosistem yang sama ataupun ekosistem yang berbeda? Ketiga, mengapa organisme tersebut secara fungsional berhubungan satu sama lain serta berhubungan dengan lingkungannya dalam caracara tertentu? Pertanyaan-pertanyaan tersebut juga dapat dimanfaatkan dalam kajian ekologis dalam bidang lain dengan memodifikasi sesuai objek kajian. Dalam kajian sastra, ketiga pertanyaan tersebut dapat dimodifikasi sebagai berikut: pertama, karya-karya sastra dan faktor-faktor lingkungan apa yang terdapat di suatu wilayah tertentu dan berapa jumlahnya; kedua, bagaimana karya-karya sastra tersebut beserta faktor-faktor lingkungannya terkait secara fungsional dan sama atau berbedakah hubungan tersebut pada lingkungan yang sama atau berbeda; ketiga, mengapa karya sastra tertentu secara fungsional berhubungan satu sama lain serta berhubungan dengan lingkungannya dalam caracara tertentu?

McNaughton dan Wolf (1989:2) juga mengemukakan bahwa kajian ekologi memiliki tujuan umum mempelajari cara organisme terintegrasi dengan lingkungannya, cara organisme mengalami modifikasi oleh lingkungannya, dan cara organisme berinteraksi satu sama lain. Rumusan tersebut oleh McNaughton dan Wolf dikemukakan dalam batasan ekologi sebagai ilmu yang berkaitan dengan biologi dan fisik. Akan tetapi, rumusan tujuan tersebut dapat menjadi 
prinsip umum kajian ekologi yang dapat diterapkan untuk kajian ekologi yang nonbiologi dan fisik dengan menyesuaikan rumusan tersebut dengan bidang kajian. Dalam kaitan dengan kajian ekologi sastra rumusan tersebut dapat dimanfaatkan dan dimodifikasi menjadi kajian mempelajari: pertama, cara karya sastra terintegrasi dengan lingkungannya, kedua, cara karya sastra mengalami modifikasi oleh lingkungannya, dan ketiga, cara karya sastra berinteraksi satu dengan lain.

Kajian sastra juga dapat menerapkan model pendekatan pada ekologi. Menurut Krebs (dalam Leksono, 2007:7) dalam ekologi, fenomena hubungan antara makhluk hidup dan lingkungan dapat dijelaskan dengan tiga pendekatan. Pertama, pendekatan deskriptif untuk menjelaskan ekologi dengan pada faktor alamiah (kebiasaan, perilaku, dan interaksi-interaksi antarorganisme dan dikaitkan dengan kumpulan vegetasi di bumi. Kedua, pendekatan fungsional menjelaskan ekologi dengan titik tekan pada dinamika dan hubungan sebab akibat dan menganalisis permasalahan umum yang biasa terdapat pada ekosistem berbeda. Ketiga, pendekatan evolusi menjelaskan organisme dan hubungan timbal baliknya sebagai produk sejarah evolusi. Untuk lebih singkatnya, pendekatan deskriptif menanyakan mengenai "apa", pendekatan fungsional menanyakan mengenai "bagaimana", dan pendekatan evolusi menanyakan mengenai “mengapa"..Ketiga pendekatan tersebut dapat diterapkan dalam kajian ekologi terhadap karya sastra. Pendekatan deskriptif dimanfaatkan untuk mendeskripsikan unsur-unsur ekologis dalam karya sastra. Pendekatan fungsional dimanfaatkan untuk menganalisis cara unsur-unsur ekologi ada karya sastra. Pendekatan evolusi dimanfaatkan untuk menganalisis sebab-sebab unsur-unsur ekologi ada dalam karya sastra. Jadi, ketiga pendekatan tersebut dapat digunakan menganalisis aspek ekologis dalam karya sastra secara komprehensif.

\section{Ragam Kajian Ekologi Karya Sastra}

Dalam kaitannya dengan kajian sastra, istilah ekologi dipakai dalam pengertian beragam. Pertama, ekologi yang dipakai dalam pengertian yang dibatasi dalam konteks ekologi alam. Kajian ekologi dalam pengertian pertama ini juga dikenal dalam dua ragam, yaitu kajian ekologi dengan menekankan aspek 
alam sebagai inspirasi karya sastra dan kajian ekologi yang menekankan pembelaan atau advokasi terhadap kerusakan lingkungan yang disebabkan oleh perbuatan manusia. Kajian ekologis sastra dalam pengertian kedua tersebut populer sebagai kajian ekokritik (ecocritic) (Glotfelty, 1996; Phillips, 2003; Garrard, 2004) . Kedua, ekologi yang dipakai dalam pengertian ekologi budaya (Carey, 1986; Sudewa, 1992; Sumardjo, 2007; Rasjid, 2010).

Kajian ekologi yang menekankan alam sebagai inspirasi mulai marak dilakukan. Hal tersebut disebabkan oleh semakin disadarinya kaitan antara sastra dan ekologinya. Pembahasan-pembahasan yang sudah dilakukan juga membuktikan bahwa ekologi memang memiliki kaitan dengan karya sastra, baik pada sastra lama atau modern, sastra lisan atau sastra tulis. Hal tersebut misalnya dapat dilihat pada beberapa karya ilmiah yang dipresentasikan dalam Konferensi Internasional Folklor Asia III yang kemudian dibukukan oleh Endraswara dkk. (2013). Karya-karya yang dimaksud, misalnya, penelitian Misnawati (2013) tentang ekopuitika Hiyang Wadian dalam Miya Padu Sapuluh di Kabupaten Barito Timur, penelitian Maspaitella (2013) tentang Nyanuk Pupule di masyarakat Olilit Timur $<$ Kabupaten Maluku Tenggara Barat.

Hiyang Wadian adalah mantera atau cerita yang diucapkan Wadian dan mengarah pada suatu tujuan. Wadian adalah orang yang memimpin ritual miya, yaitu ritual tradisional kematian tertinggi dalam upacara adat Dayak Maanyan Paju Sapuluh di Kabupaten Barito Timur. Upacara tersebut dilaksanakan khusus oleh umat Kaharingan dalam rangka mengantar roh atau arwah seseorang ke alam peristirahatan terakhir. Analisis Misnawati menunjukkan bahwa dalam teks mantra-mantra Hiyang Wadian banyak ditemukan pemanfaatan lingkungan alam seperti binatang, air, langit, untuk mereprentasikan tingkah laku manusia. Lingkungan alam menjadi inspirasi puitika mantra Hiyang wadian.

Penelitian Maspaitella (2013) juga menunjukkan peran lingkungan alam sebagai inspirasi dan pembentuk nyanuk pupule. Nyanuk pupule merupakan bentuk foklor lisan yang tergolong dalam ungkapan tradisional, sebagai simbol yang digunakan oleh masyarakat Olilit Timur ketika bertutur atau menyampaikan pesan. Nyanuk pupule merupakan kata yang membungkus kata referensinyasehingga makna yang dimunculkan secara referensial berbeda dengan 
makna maksudnya. Misalnya, "Seperti laba-laba sedang membuat sarang”, "Kami menyukai kalabasa dan bakul di dalam rumah ini”.

Kajian sastra dengan perspektif ekologi alam yang dikenal dengan nama teori ekokritik, telah banyak dilakukan oleh peneliti sastra. Ekokritik kali pertama dipakai pada akhir 1980 di Amerika dan di awal 1990 di Inggris dengan istilah green studies. Berkembangnya ekokritik di Amerika ditandai dengan berdirinya The Association for the Study of Literature and Environment (ASLE) pada tahun 1992 yang secara rutin mengadakan pertemuan untuk mencari kemungkinan kerja sama antara peneliti sastra dengan aktivis gerakan lingkungan (Arimbi, 2010:127).

Pada intinya ekokritik, sebagaimana dikemukakan oleh Glotfety (!996:xix) adalah kajian hubungan antara sastra dan lingkungan fisik, kajian sastra yang berpusat pada dunia (earth-centered). Kajian yang juga disebut sebagai kajian hijau tersebut antara lain memperbincangkan cara alam diwakili dalam puisi, cara menjelaskan ciri-ciri genre kesusastraan alam sekitar, cara krisis alam sekitar memasuki kesusastraan komtemporer, dan sebagainya. Menurut Garrard (2004:14) pengetahuan ekologi bukan hanya untuk melihat harmoni dan stabilatas lingkungan tetapi juga untuk mengetahui sikap dan perilaku manusia. Oleh karena itu, menurutnya analisis ekokritik bersifat interdisipliner yang merambah disiplin ilmu lain, yaitu sastra, budaya, filsafat, sosiologi, psikologi, sejarah lingkungan, politik dan ekonomi, dan studi keagamaan.

Di Barat, teori ekokritik berkembang pesat terbukti dengan terbitnya berbagai buku teori ekokritik dan pembahasan karya sastra dengan perspektif ekokritik. Beberapa buku yang dimaksud, misalnya, Egan (2006) membahas ekopolitik (ecopolitic) karya-karya Shakespeare, Gairn (2008) membahas ekologi karya-karya sastra Skotlandia, Estok (2011) membahas ekopobia (ecophobia) karya-karya Shakespeare.

Di Indonesia, ekokritik tersebut akhir-akhir ini juga menarik perhatian peneliti sastra. Hal tersebut dibuktikan dengan munculnya tulisan-tulisan yang membahas ekokritik dan penerapan ekokritik untuk menelaah karya sastra. Kajian ini bahkan telah mengalami perkembangan pesat dengan munculnya kajian-kajian 
interdisipliner seperti ekofeminisme (Saraswati, 2011) dan ekologi imperalisme (Rosyida, 2011).

Ekokritik memiliki ciri khusus yaitu keberpihakannya pada kerusakan atau krisis ekologi ((Bertens, 2008:203). Oleh karena itu, ekokritik sering disebut sebagai pendekatan kritis, kritik yang berbasis bumi atau disebut juga green studies (Kerrigde dalam Arimbi, 2010:127). Di samping itu, konsep-konsep yang digunakan dalam ekokritik memiliki pengertian yang berbeda dengan kajian ekologi lainnya. Misalnya, konsep ekopolitik dalam ekokritik digunakan dalam pengertian kebijakan politik yang berkaitan dengan keberadaan alam. Keputusan politik mengenai perang dan perlombaan senjata, misalnya, akan mengancam masa depan alam (Egan, 2006:17-50). Konsep ekososial dalam ekokritik digunakan dalam pengertian situasi sosial yang berpengaruh pada permasalahan ekologi (Garrard, 204:28).

Kajian sastra dengan perspektif ekologi budaya dilakukan oleh Carey (1986) terhadap naskah-naskah yang berisi Perang Dipanagara atau babad Dipanagara. Sesuai dengan karya yang diteliti, konteks budaya yang dimaksud adalah budaya Jawa pada awal abad ke-19. Menurut Carey, sifat-sifat khusus kebudayaan Jawa merupakan landasan yang penting bagi pemahaman historis dan pandanganpandangan para penulis ketiga babad tersebut. Permasalahan legitimasi dan otoritas kekuasaan selalu menjadi tema penting dalam babad tersebut dan permasalahan pamrih merupakan pertimbangan sentral di dalam falsafah orang Jawa mengenai kekuasaan. Pencarian legitimasi serta pembahasan permasalahan pamrih tersebut telah dipostulasikan dalam pandangan dan pengertian kebudayaan dan kosmik Jawa yang tradisional. Pada semua babad tersebut gambarangambaran yang diambil dari cerita-cerita wayang, terutama Arjuna Wiwaha dan Bratayuda, dipergunakan untuk melukiskan sekali kelompok masyarakat keraton, begitu kuat pemahamannya tentang wayang, sehingga tidak mustahil mereka menggeneralisasi perang Dipanagara sebagaimana perang baratayuda. Ketiga babad tersebut juga memperlihatkan peran ramalan Jayabaya pada masyarakat Jawa pada permulaaan abad sembilan belas. Pemahaman orang Jawa tentang ramalan-ramalan Jayabaya dengan didukung oleh kekacauan ekonomi politik sebelum pecah perang, telah membentuk harapan akan munculnya Ratu Adil yang 
juga menjadi motif dilangsungkannya perang. Demikian juga, ketiga babad tersebut juga membicarakan masalah dunia spiritual Jawa yang mempunyai arti penting bagi pemahaman historis konsep-konsep orang Jawa mengenai kekuasaan pada waktu itu, termasuk mengenai konsep wahyu, pusaka, tempat suci, mimpi, dan lain sebagainya.Oleh karena itu, untuk memahami karya sastra yang dimaksud, pemahaman dan kepercayaan orang Jawa awal abad ke-19, terutama pemahaman dan kepercayaan tentang wayang, mitos Ratu Adil seperti dalam ramalan Jayabaya, wahyu, dan pusaka, yang menjadi konteks penciptaannya harus diperhitungkan. Dalam penelitian tersebut, Carey membuktikan bahwa penulisan naskah-naskah tentang Perang Dipanagara itu diilhami oleh cerita Arjuna Wiwaha dan Bratayuda dan juga kepercayaan terhadap Ratu Adil dan wahyu keraton.

Kajian sastra dengan perspektif ekologi budaya juga dilakukan oleh Sudewa (1992) dalam membahas pandangan tentang individu dan masyarakat dalam Serat Wulangreh (SWR). Kajian yang menggunakan sumber sebuah karya sastra yang spesifik tersebut bertujuan agar dapat mengungkapkan sosok paham filsafat jawa di dalam menanggapi tantangan zaman suatu kurun waktu dan untuk memberi gambaran kepada masyarakat luas bahwa paham filsafat jawa bukan paham yang statis, melainkan paham yang bergeser dari waktu ke waktu.

Dalam kajian ini, Sudewa mengemukakan ekologi sosial budaya pada pergantian abad XVIII-XIX dengan memulai uraiannya mengenai perjanjian Giyanti tahun 1756 yang membagi Kerajaan Mataram menjadi Kasunanan Surakarta dan Kasultanan Yogyakarta. Perjajnjian tersebut selain memberi kesempatan pihak VOC untuk mengeksploitasi daerah Pesisir Utara Jawa ruparupanya juga merupakan pengenalan ilmu pengetahuan dan teknologi Barat kepada masyarakat Jawa.Menurut Sudewa, data sosio-demoografis yang diungkapkan oleh Ricklefs dan data sosio-ekonomis yang diungkapkan oleh Carey pada peargantian abad XVIII/XIX ternyata sejajar dengan yang terungkap di dalam karya sastra sezaman yang banyak mengungkapkan kecemasan budaya. Ekologi sosial budaya yang terjadi pada awal abad XIX tersebut memengaruhi sistem makna yang diletakkan oleh sang pujangga dalam SWR.

Karya-karya sastra yang digolongkan Sudewa masuk dalam ekologi sastra SWR ada dua jenis. Pertama, karya-karya yang memberikan gambaran manusia 
ideal. Yang termasuk jenis karya ini adalah jenis karya-karya epik naratif Jawa Kuna yang digubah kembali ke dalam bahasa Jawa Baru, yaitu Serat Rama Jarwa, Serat Bratayuda, Serat Lokapala, dan Serat Wiwahajarwa. Selain itu, Serat Centhini juga termasuk dalam kategori jenis karya sastra yang memberi gambaran manusia ideal. Kedua, karya-karya yang meberi gambaran perilaku ideal. Jenis karya-karya yang dimaksud adalah jenis karya-karya sastra piwulang, yaitu Serat Nitisruti, Serat Nitipraja, Serat Sewaka, Serat Wedatama, dan Serat Panitisastra. Karya-karya tersebut memberikan dimensi makna pada SWR.

Kajian sastra dengan perspektif ekologi budaya karya sastra juga dilakukan oleh Sumardjo (2007) dalam mengaji sastra lakon Indonesia. Kajian tersebut dimaksudkan untuk melihat perkembangan penulisan sastra lakon di Indonesia yang dimulai sejak awal abad ke-20. Dalam kajian tersebut, Sumardjo menggunakan latar belakang zaman, latar belakang teater dan sastra, dan latar belakang penulis naskah lakon sebagai landasan untuk memahami keadaan naskah lakon. Untuk kepentingan kajian tersebut, pembicaraan naskah lakon Indonesia dilihat berdasarkan pembabakan sejarah politik di Indonesia, yakni sejarah pergantian sistem-sistem politiknya yang terbagi dalam enam kelompok dan periode: (1) lakon-lakon zaman kolonial (1900-1942); (2) lakon-lakon zaman Jepang; (3) lakon-lakon zaman revolusi; (4) lakon-lakon zaman demokrasi liberal (1950-1959); (5) lakon-lakon zaman demokrasi terpimpin (1959-1966); (6) lakonlakon zaman orde baru (1966-1998).

Rasjid (2010) membahas segi ekologi sosial desa dan kota terhadap sastra Hindia Belanda, sastra Melayu Modern, dan sastra sastra Balai Pustaka. Menurut Rasjid, kajian ekologis terhadap karya-karya tersebut menunjukkan adanya ragam ekologi yang bergeser dari penguasaan laut, penaklukan desa, dan pembangunan kota yang melibatkan kontradiksi lembaga militer, agama, instansi pendidikan, dan birokrasi politik. Adanya ragam ekologi tersebut dapat dibaca sebagai bagian pembacaan kritis terhadap alur perkembangan konteks sosial historis bangsa pada suatu masa. Aspek ekologis karya-karya tersebut juga menunjukkan bahwa bangsa Indonesia, sebelum dan sesudah merdeka, ternyata belum beranjak sebagai bangsa yang menjadi korban eksploitasi dari keserakahan, kepentingan- 
kepentingan kekuasaan yang sering berujung pada kekerasan, penderitaan, dan jatuhnya korban.

\section{SIMPULAN}

Ada kesamaan antara fenomena karya sastra dan organisme dalam ekosistemnya. Oleh karena itu, paradigma ekologi dapat diterapkan dalam kajian sastra. Walaupun sudah banyak penelitian karya sastra dari segi ekologi, tetapi ekologi sebagai pendekatan terhadap karya sastra belum banyak disadari atau paling tidak belum populer sebagaimana penelitian interdisiplin sastra lainnya seperti sosiologi sastra, psikologi sastra, antropologi sastra, dan lain sebagainya. Oleh karena itu, sampai saat ini paradigma ekologi sebagai kajian sastra belum jelas sosoknya. Penelitian-penelitian teoritis dan uji coba-uji coba dalam kajian sastra selanjutnya diperlukan agar kelak dapat dirumuskan menjadi sebuah pendekatan ekologi terhadap sastra yang mapan

Pendekatan ekologi terhadap karya sastra akan memperlihatkan unsur-unsur ekologi dalam karya sastra, proses unsur-unsur ekologi berinteraksi dengan karya sastra, dan sebab-sebab unsur ekologi ada dalam karya sastra. Oleh karena itu, pendekatan ekologi terhadap karya sastra bukan hanya untuk memahami karya sastra, tetapi juga untuk memahami posisi suatu karya sastra dalam hubungan dengan karya-karya sastra lainnya.

\section{DAFTAR PUSTAKA}

Arimbi, Maimunah D.A.. 2010. "Ecocriticism: Mencari Solusi Alternatif Persoalan Ekologis Melalui Pembacaan Karya Sastra”. Dalam Sastra \& Perubahan Sosial. Kumpulan Makalah Seminar. Solo: Fakultas Sastra dan Seni Rupa Publishing.

Bertens, Hans. 2008. Basics Literary Theory. London and New York: Taylor \& Francis.

Egan, Gabriel. 2006. Green Shakespeare: From Ecopolitics to Ecocriticsm. London and New York: Routledge.

Endraswara, Suwardi dkk.(Ed.) 2013. Folklor dan Folklife dalam Kehidupan Modern: Kesatuan dan Keberagaman. Yogyakarta: Pustaka Timur. 
Estok, Simon C. 2011. Ecocriticism and Shakespeare: Reading Ecophobia. New York: Palgrave Macmillan.

Fabiola. 2009. "Menuju Peitika Melayu-Indonesia: dari Pantun Nasihat BruneiMalaysia hingga Wayang Jawa dan Mabebasan Bali”. Dalam Pelangi Sastra dan Budaya. Surabaya: Unesa University Press.

Gairn, Lousia. 2008. Ecology and Modern Scottish Literature. Edinburgh: Edinburgh University Press.

Garrard, Greg. 2004. Ecocriticism. London and New York: Routledge.

Huggan, Graham dan Tiffin, Helen. 2010. Postcolonial Ecocriticism: Literature, Animal, Environment. London and New York: Routledge.

Kridalaksana, Harimurti. 1982. Kamus Linguistik. Jakarta: Gramedia.

Leksono, Amin Setyo. 2007. Ekologi: Pendekatan Deskriptif dan Kuantitatif. Malang: Bayumedia Publishing.

Maspaitella, Martha. 2013. "Lingkungan Sebagai Pembentuk Folklor Lisan Nyanuk Pupule di Masyarakat Olilit Timur, Kabupaten Maluku Tenggara Barat”. dalam Endraswara, Suwardi dkk.(Ed.) 2013. Folklor dan Folklife dalam Kehidupan Modern: Kesatuan dan Keberagaman. Yogyakarta: Pustaka Timur.

McNaughton, S.J. dan Wolf, Larry L. 1989. Ekologi Umum. New York: World Bank Educaation IX Project.

Misnawati. 2013. "Hiyang Wadian dalam Miya Padu Sapuluh di Kabupaten Barito Timur: Kajian Ekopuitika dan Interpretatif Simbolik". dalam Endraswara, Suwardi dkk.(Ed.) 2013. Folklor dan Folklife dalam Kehidupan Modern: Kesatuan dan Keberagaman. Yogyakarta: Pustaka Timur.

Odum, Eugene P. 1996. Dasar-Dasar Ekologi.Yogyakarta: Gadjah Mada University Press.

Poerwanto, Hari. 2005. Kebudayaan dan Lingkungan dalam Perspektif

Antropologi. Yogyakarta: Pustaka Pelajar.

Pujiharto. 2010. Perubahan Puitika dalam Fiksi Indonesia dari Modernisme ke Pascamodernisme. Yogyakarta: Elmatera. 
Rasjid, Abdul Aziz. 2010. "Ragam Ekologi Sastra”. http://cabiklunik blogspot.com/2010/05/ragam- ekologi- sastra html.

Rosyidah, Usma Nur Dian. 2011. "Ecological Imperalism dalam Novel Anak Bakumpai Terakhir Karya Yuni Nurmalia”.

Saraswati, Rina. 2011. "Tanah Tabu Karya Anindita S. Thayf: Resistensi Perempuan Papua dalam Perspektif Ekofeminisme”. Dalam Pustaka, Jurnal Ilmu-Ilmu Budaya Volume XI Nomer 2 Hal. 129-139. Depansar: Yayasan Guna Widya, Fakultas Sastra Unud.

Sastrapratedja (Ed.). 1982. Manusia Multi Dimensional: Sebuah Renungan Filsafat. Jakarta: Gramedi

Solomon, Robert C. dan Higgins, Kathleen M. 2002. Sejarah Filsafat. Terjemahan Saut Paaribu. Yogyakarta: Bentang

Stanton, Robert. 2012. Teori Fiksi. Terjemahan Sugiastuti dan Rossi Abi Al Irsyad. Yogyakarta: Pustaka Pelajar.

Sudewa, A. 1992. "Individu dan Masyarakat dalam Serat Wulangreh". Basis No. 5 XLI Mei.

Sumardjo, Jacob. 2007. Ekologi Sastra Lakon Indonesia. Bandung: Kelir.

Suparwa, I. Nyoman. 1988. "Ekologi Bahasa dan Pengaruhnya dalam Dinamika Kehidupan Bahasa Melayu Loloan Bali”. http://ojs.unud.ac.id/index $\mathrm{php} / \mathrm{blje} / \mathrm{download} / 2421 / 1649$.

Teeuw, A. 2013. Sastra dan Ilmu Sastra: Pengantar Ilmu Sastra. Jakarta: Pustaka Jaya. 